\title{
Milk production and blood metabolites of dairy cattle as influenced by thermal-humidity index
}

\author{
Thapelo W. Kekana ${ }^{1} \cdot$ Florence V. Nherera-Chokuda ${ }^{1} \cdot$ Mukengela C. Muya ${ }^{1} \cdot$ Kabelo M. Manyama $^{1}$. \\ Khoboso C. Lehloenya ${ }^{2}$
}

Received: 12 September 2017 / Accepted: 9 January 2018 / Published online: 25 January 2018

(C) The Author(s) 2018. This article is an open access publication

\begin{abstract}
The effects of high thermal stress on serum protein metabolites, milk production of transition dairy cows in semi-arid areas in South Africa were evaluated. Forty, \pm 8 months pregnant, Jersey heifers ( \pm 26 months) in zero grazing management were selected during summer from two semi-arid communal areas. Summer thermal-humidity index (THI) of the areas were THI-1 (72-83: extreme caution) and THI-2 (75-87: danger). Blood samples were collected (21 days pre-partum, and 21 and 75 days postpartum) and analysed for serum protein metabolites. Milk yield was recorded daily and samples collected for milk fat, protein, lactose and urea nitrogen analysis. Heifers in THI-2 had lower $(P<0.05)$ total serum proteins, albumin and blood urea nitrogen than THI-1. Post-calving, cows in THI-1 had higher $(P<0.05)$ TP $(73.4$ vs $67.9 \mathrm{~g} / 1)$ and BUN $(4.61 \mathrm{vs} 3.77 \mathrm{mmol} / \mathrm{l})$ at $21 \mathrm{DIM}$, and lower (P creatinine at 21 and 75 DIM than THI-2 group. Milk yield, fat and protein in THI-2 were all lower $(P<0.05)$ than THI-1 21DIM. The results confirm that heat stress affects utilisation of nutrients in transition dairy cows.
\end{abstract}

Keywords Blood proteins $\cdot$ Milk production $\cdot$ Smallholder dairy cows

\section{Introduction}

Milk production contributes to nutrition and income security in resource poor environments of sub-Saharan Africa. However, poor animal nutrition and heat stress affect immunity and performance of dairy cows. Pregnant and lactating cows are more susceptible to metabolic disorders due to high nutrient demands for foetal growth, growth and lactation (Polsky and von Keyserlingk 2017; De Rensis et al. 2015) and increase maintenance requirements for heat dissipation (Jiminez 2013). Dairy cattle in subtropical and tropical areas are subjected to extended periods of high temperature and sometimes high relative humidity (high temperature-humidity index THI). The thermal comfort zone of dairy cows is -13 to $25{ }^{\circ} \mathrm{C}$

Thapelo W. Kekana

KekanaT@arc.agric.za

1 Livestock Nutrition Unit, Agricltural Research Council, P. Bag x 02, Irene 0062, South Africa

2 Faculty of Science and Agriculture, University of Zululand, KwaDlangezwa 3886, South Africa
(Kadzere et al. 2002; Bickert and Mattiello 2016), beyond which heat stress occurs. When rectal temperature exceeds the threshold $\left(39.5{ }^{\circ} \mathrm{C}\right)$, cows pant, drool and subcutaneous blood flow increase (Garner et al. 2017). It is noted that maintenance energy requirements surge when ambient temperatures exceed $35{ }^{\circ} \mathrm{C}$, the feed intake declines, which affect rumination and the synthesis of milk precursors (Könyves et al. 2017).

In Sub-Saharan Africa, drought and dry seasons are becoming more frequent and longer in duration due to the $E l$ Nino effect. The Intergovernmental Panel on Climate Change (IPCC) (2014) indicated that global temperatures would rise by $1.8-4{ }^{\circ} \mathrm{C}$ by the end of the twenty-first century. Death in cows due to hyperthermia may occur (Cox et al. 2016). High milk-producing dairy cows succumb to heat stress earlier than low milk-producing cows ( $\mathrm{Hu}$ et al. 2016) as immunity is lowered by the stress of milk production (Tao and Dahl 2013). Management strategies including high-energy feeds, watering, shade, tunnels and sprinklers may alleviate the problem (Nickerson 2014). The effects of very high temperatures on immunity of transitioning dairy cows in semi-arid areas should be assessed as that has implications on food security of poorer communities. The objective of the study was to determine effects of high thermal stress on serum proteins 
and milk production of transitioning and early lactating dairy cows in semi-arid communal areas of South Africa.

\section{Material and methods}

Forty pregnant Jersey heifers $(310 \pm 40-\mathrm{kg}$ live weight; BCS $2.5-3.5 ; \pm 26$ months) in zero grazing management were selected from two communal areas of Limpopo province, South Africa ((site1:24.8335 $\mathrm{S}, 29.9741^{\circ} \mathrm{E}$ and site2:22.7696 $\mathrm{S}$, $\left.29.9741^{\circ} \mathrm{E}\right)$. Temperature-humidity indices for the period October-December 2015 were calculated from ambient temperature-AT and RH-relative humidity (ISWC, ARC; 2015/2016). The NRC (1971) equation was applied to determine THI (site1:72-83 and site2:75-87). Schüller et al. (2014) defined THI categories for dairy cattle as optimum: $<65$ and danger: 75-80.

Pregnant heifers were housed in partially roofed sheds and fed $4 \mathrm{~kg} /$ animal/day dry cow concentrate $(92.4 \% \mathrm{DM}$; $15.1 \% \mathrm{CP} ; 3.9 \% \mathrm{Fat} ; 41 \% \mathrm{NDF} ; 9.4 \% \mathrm{ADF}$ ) and postpartum$6 \mathrm{~kg}$ /animal/day lactating concentrate $(90.4 \% \mathrm{DM} ; 17.3 \% \mathrm{CP}$; 2.7\%Fat; 39.3\% NDF; 7.5\%ADF) with ad adlib Eragrostis curvular hay and clean water. Cows were hand milked $(06 \mathrm{H} 00)$ and calves suckled during the day and separated from dams overnight. Composite milk samples were collected from morning milking sessions weekly until 75 DIM and analysed for fat, CP, MUN and lactose using the System-4000-Infrared Analyser (Foss-Electric, Hillerod).

Blood was collected in anti-coagulant tubes from the coccygeal vein before concentrate feeding at 21-day pre-partum and 21 and 75 DIM. Post-blood centrifugation $(1000 \times g$ : $10 \mathrm{~min}$ ), the separated serum was stored pending analysis of total proteins (TP) (Doumas and Biggs 1972; Weichselbaum 1946) and creatinine (Cr) (Tietz 1995). Globulin were calculated as the difference between TP and Alb. Enzymatic methods (Tietz 1995) were used to determine blood urea (BUN). Data was analysed using analysis of variance procedures (ANOVA) for a complete randomised design (CRD) in Statistical Analysis System version 9.0 (SAS 2009). Fisher's least significant difference (LSD) method was used to separate means and difference were declared at $P<0.05$.

\section{Results}

Pregnant heifers in THI-2 had lower $(P<0.05)$ TP, Alb and BUN than THI-1 (Table 1). Blood Crea and Glob precalving were not affected $(P<0.05)$. Lactating cows (THI-2) had higher $(P<0.05)$ TP and BUN at 21 DIM, and higher $(P<0.05)$ creatinine at +21 and +75 DIM than THI- 1 cows. At 21 days, milk yield, fat and protein content differed $(P<0.05$; Table 2$)$ and no differences were noted thereafter except in MUN.
Table 1 Serum protein metabolites in of primiparous Jersey cows in semi-arid communal areas

\begin{tabular}{|c|c|c|c|}
\hline Parameters & THI-1 (72-83) & THI-2 (75-87) & SEM \\
\hline \multicolumn{4}{|l|}{ Pre-calving ( -21 days) } \\
\hline Total protein $(\mathrm{g} / \mathrm{L})$ & $72.6^{\mathrm{b}}$ & $78.3^{\mathrm{a}}$ & 1.53 \\
\hline Blood urea nitrogen $(\mathrm{mmol} / \mathrm{L})$ & $4.9^{\mathrm{b}}$ & $5.9^{\mathrm{a}}$ & 0.28 \\
\hline Creatinine $(\mu \mathrm{mol} / \mathrm{L})$ & 126 & 138 & 5.71 \\
\hline Albumin $(\mathrm{g} / \mathrm{L})$ & $31.5^{\mathrm{b}}$ & $39.1^{\mathrm{a}}$ & 2.64 \\
\hline Globulin (mmol/L) & 41.1 & 39.3 & 2.79 \\
\hline \multicolumn{4}{|l|}{ Post-calving } \\
\hline \multicolumn{4}{|l|}{ Total protein $(\mathrm{g} / \mathrm{L})$} \\
\hline $21 \mathrm{DIM}$ & $67.9^{\mathrm{b}}$ & $73.4^{\mathrm{a}}$ & 1.34 \\
\hline 75 DIM & 62.9 & 65.5 & 1.32 \\
\hline \multicolumn{4}{|l|}{ Blood urea nitrogen $(\mathrm{mmol} / \mathrm{L})$} \\
\hline 21 DIM & $3.8^{\mathrm{b}}$ & $4.6^{\mathrm{a}}$ & 0.21 \\
\hline 75 DIM & 4.2 & 4.4 & 0.51 \\
\hline \multicolumn{4}{|l|}{ Creatinine $(\mu \mathrm{mol} / \mathrm{L})$} \\
\hline $21 \mathrm{DIM}$ & $97.2^{\mathrm{b}}$ & $127^{\mathrm{a}}$ & 7.88 \\
\hline 75 DIM & $78.9^{\mathrm{b}}$ & $130^{\mathrm{a}}$ & 3.28 \\
\hline \multicolumn{4}{|l|}{ Albumin $(\mathrm{g} / \mathrm{L})$} \\
\hline 21 DIM & 32.2 & 36.3 & 2.15 \\
\hline 75 DIM & 28.6 & 30.7 & 2.16 \\
\hline \multicolumn{4}{|l|}{ Globulin (mmol/L) } \\
\hline $21 \mathrm{DIM}$ & 35.8 & 37.2 & 2.42 \\
\hline 75 DIM & 34.4 & 34.8 & 2.64 \\
\hline
\end{tabular}

Means with the same superscript in the same row are not significantly different at $P<0.05$

21 and $75=$ days in milk, THI thermo-humidity index, SEM standard error of mean

\section{Discussion}

Although the Jersey cows were supplemented at $6 \mathrm{~kg}$ / cow/day, milk yield was low. Karimi et al. (2015) indicated that heat stress reduce feed intake affecting synthesis of milk precursors. During early lactation, feed intake is low and heat stress exacerbated the problem. The low milk yield from THI-2 could be associated with low albumin and globulin concentrations (Das et al. 2016), which explains indifferences in milk composition post-21 DIM as also noted (Bernabucci et al. 2014; Garner et al. 2017). Although blood TP and BUN did not differ at 75 DIM, the metabolites were low in THI-2.

Lamp et al. (2015) reported that creatinine synthesis in healthy animals is constant and depends on muscle mass and protein intake, which influence the levels in serum. High protein oxidation in pregnant animals and during early lactation compensates for low nutrient intake to support the demands for pregnancy and milk production. Proteins oxidation causes high muscle proteolysis that increases plasma urea concentrations (Greenwood and Café 2007) 
Table 2 Early lactation milk yield and composition of primiparous Jersey cows in semi-arid communal areas

\begin{tabular}{llll}
\hline Parameter & THI-1 (72-83) & THI-2 (75-87) & SEM \\
\hline Mean 1-21 days in milk & & & \\
Milk yield (litres/day) & $12.4^{\mathrm{a}}$ & $10.6^{\mathrm{b}}$ & 0.79 \\
Fat (\%) & $4.5^{\mathrm{a}}$ & $3.1^{\mathrm{b}}$ & 0.41 \\
Protein (\%) & $3.6^{\mathrm{a}}$ & $2.6^{\mathrm{b}}$ & 0.56 \\
Urea nitrogen (mg/day) & 13.7 & 11.4 & 1.96 \\
Lactose (\%) & 4.8 & 3.9 & 0.37 \\
Mean 22-75 days in milk & & & \\
Milk yield (litres/day) & 8.6 & 8.4 & 0.79 \\
Fat (\%) & 4.5 & 4.5 & 0.41 \\
Protein (\%) & 3.5 & 3.2 & 0.56 \\
Urea nitrogen (mg/day) & $10.2^{\mathrm{a}}$ & $18.3^{\mathrm{b}}$ & 1.96 \\
Lactose (\%) & 4.4 & 4.6 & 0.37 \\
\hline
\end{tabular}

${ }^{\mathrm{a}, \mathrm{b}}$ In the same row, values with different superscripts are significantly different $P<0.05$

$T H I$ temperature-humidity index, SEM standard error of mean

causing increase in creatinine. The high THI in site 2 could affect kidney function and induce clearance of creatinine and circulation of urea (Higashiyama et al. 2014).

Studies by Zhang et al. (2014) and Cowley et al. (2015) confirm observations noted in this study. The imbalance in rumen protein and energy increase rumen $\mathrm{N}$ balance affecting plasma urea. Cow mortality in THI2 was $9 \%$ and none in THI-1, and heat stress was implicated.

\section{Conclusion/recommendations}

The current study revealed the negative impact of high ambient temperatures on performance of transition dairy cows especially on smallholder farms as producers only provided partial roof shed to mitigate prolonged heat. Milk production was low which would reduce sustainability of milk businesses under such high heat conditions. The goal for achieving economic and food security for the rural poor through dairy farming can only be realised through concerted research on new technologies to mitigate heat stress.

Acknowledgements The authors appreciate the Department of Rural Development and ARC-Animal Production, SA.

Compliance with ethical standards The study complied with the Ethical Standard of animal ethics committee of the API, Irene, South Africa.

Conflict of interest The authors declare that they have no conflict of interest.
Open Access This article is distributed under the terms of the Creative Commons Attribution 4.0 International License (http:// creativecommons.org/licenses/by/4.0/), which permits unrestricted use, distribution, and reproduction in any medium, provided you give appropriate credit to the original author(s) and the source, provide a link to the Creative Commons license, and indicate if changes were made.

\section{References}

Bernabucci, U., Biffani, S., Buggiotti, L., Vitali, A., Lacetera, N., \& Nardone, A., 2014. The effects of heat stress in Italian Holstein dairy cattle. Journal of Dairy Science, 97, 471-486

Bickert, W.G., \& Mattiello, S., 2016. Stress in dairy Animals: Cold stress: Management considerations. https://doi.org/10.01016/B978-0-08100596-5.01055-6

Cowley, F.C., Barber, D.G., Houlihan, A.V. \& Poppi, D.P., 2015. Immediate and residual effects of heat stress and restricted intake on milk protein and casein composition and energy metabolism, Journal of Dairy Science, 98, 2356-2368

Cox, B., Gasparrini, A., Catry, B., Delcloo, A., Bijnens, E., Vangronsveld, J., \& Nawrot, T.S., 2016. Mortality related to cold and heat. What do we learn from dairy cattle? Environmental research, 149, 231-238

Das, R., Sailo, L., Verma, N., Bharti, P., \& Saikia, J., 2016. Impact of heat stress on health and performance of dairy animals: A review. Veterinary world, 9, 260

De Rensis, F., Garcia-Ispierto, I., \& López-Gatius, F., 2015. Seasonal heat stress: Clinical implications and hormone treatments for the fertility of dairy cows. Theriogenology, 84, 659-666

Doumas, B.T., \& Biggs, H.G., 1972. Determination of serum albumin. In Standard Methods of Clinical Chemistry (Ed. GA Cooper), Academic Press. Inc. New York, 7, 175

Garner, J.B., Douglas, M., Williams, S.R.O., Wales, W.J., Marett, L. C., DiGiacomo, K., \& Hayes, B.J., 2017. Responses of dairy cows to short-term heat stress in controlled-climate chambers. Animal Production Science, 57, 1233-1241

Greenwood, P.L. \& Café, L.M., 2007. Prenatal and pre-weaning growth and nutrition of cattle: Longterm consequences for beef production. Animal, 1, 1283-1296

Higashiyama, Y., Komatsu, T., Fukasawa, M., Higashiyama, M., Ikeda, K., Ueda, Y., \& Asakuma, S., 2014. Comparison of urinary cortisol levels in Holstein and Japanese Shorthorn cows in response to breeding system and heat stress. Journal of Animal Science Advances, 4, 1009-1016

Hu, H., Zhang, Y., Zheng, N., Cheng, J., \& Wang, J., 2016. The effect of heat stress on gene expression and synthesis of heat-shock and milk proteins in bovine mammary epithelial cells. Animal Science Journal, 87, 84-91

Intergovernmental Panel on Climate Change (IPCC), 2014. Climate Change: Synthesis Report; Summary for Policymakers. 2014. Accessed on 02 May 2017

Jiminez, D. L., 2013. Heat stress in dairy Jainu cows: implications and nutritional management. PUBVET, 7, 25

Kadzere, C. T., Murphy, M. R., Silanikove, N., \& Maltz, E., 2002. Heat stress in lactating dairy cows: a review. Livestock Production and Science, 77, 159-91

Karimi, M.T., Ghorbani, G.R., Kargar, S., \& Drackley, J.K., 2015. Lategestation heat stress abatement on performance and behaviour of Holstein dairy cows. Journal of Dairy Science, 98, 6865-6875

Könyves, T., Zlatković, N., Memiši, N., Lukač, D., Puvača, N., Stojšin, M., \& Miščević, B., 2017. Relationship of temperature-humidity index with milk production and feed intake of Holstein-Friesian 
cows in different year seasons. The Thai Journal of Veterinary Medicine, 47, 15-23

Lamp, O., Michael, D., Winfried, O., Manfred, M., Gerd, N. \& Björn, K., 2015. Metabolic Heat Stress Adaption in Transition Cows: Differences in Macronutrient Oxidation between Late-Gestating and Early-lactating German Holstein Dairy Cows. Plos One, 10, $\mathrm{e} 0125264$

National Research Council, 1971. A guide to environmental research on animals. (National Academic Science, Washington, DC

Nickerson, S.C., 2014. Management strategies to reduce heat stress prevent mastitis and improve milk quality in dairy cows and heifers. University of Georgia. Bulletin, 1426.

Polsky, L., \& von Keyserlingk, M.A., 2017. Invited review: Effects of heat stress on dairy cattle welfare. Journal of Dairy Science, 100, $8645-8657$

SAS, 2009. Statistical Analysis System Institute Inc. Users Guide, Version 9.1. Cary, NC, USA
Schüller, L.K., Burfeind, O., \& Heuwieser, W., 2014. Impact of heat stress on conception rate of dairy cows in the moderate climate considering different temperature-humidity index thresholds, periods relative to breeding, and heat load indices. Theriogenology, $81,1050-1057$

Tao, S., \& Dahl, G.E., 2013. Invited review: heat stress effects during late gestation on dry cows and their calves. Journal of Dairy Science, 96 , 4079-4093

Tietz, N.W., 1995. Clinical guide to laboratory tests, WB Saunders Company, Philadelphia.

Weichselbaum, T. E., 1946. An accurate and rapid method for the determination of proteins in small amounts of blood serum and plasma. Anim. Journal of Clinical Pathology, 16, 40

Zhang, F.J., Weng, X.G., Wang, J.F., Zhou, D., Zhang, W. \& Zhai, C.C., 2014. Effects of temperature-humidity index and chromium supplementation on antioxidant capacity, heat shock protein 72 , and cytokine responses of lactating cows. Journal of Animal Science, 92, 3026-3034 